\title{
Gender Inequality: Work Place Issues
}

\author{
Syed Shoeb Ahmed Muhammad Naeem Akhtar \\ Department of Public Administration, University of Karachi
}

\begin{abstract}
Women have always been a most integral part of workforce. If we stretch back to the eighteenth century women not only used to work at their homes but also outside their houses, mostly as a maid. After the industrial revolution number of women entering in to the workforce increases and this change further increases with the time. However, this increase didn't assure them that they will have equal rights or will be treated on fair basis rather than on gender basis. Today when we are living in a fast paced technological era, females are still facing problems at workplace in many different ways. This paper is intended to cover all those issues which has been identified in different studies moreover, an analysis on factors behind them. The first part of this paper will briefly discuss the historical background of women participation at workplace, then this part will be followed by discussion on different researches and studies. In this paper six different studies are discussed that reveals six or more factors that cause inequality and discrimination on gender basis at workplace. Each study is discussed and analyzed with the help of its finding. The statistics provided by those researches help to understand the real picture of the issue. The last part, conclusion, summarizes the whole research. It roundup and highlights the main issues which is discussed in the earlier part. It will be helpful for the reader to find the work of the current research done in this particular area of study.
\end{abstract}

Keywords: Discrimination, Workforce, Inequality, Industrial Revolution

DOI: $10.7176 / \mathrm{JESD} / 11-20-05$

Publication date:October $31^{\text {st }} 2020$

\section{Introduction}

A woman being a part of workforce is not a new concept. In mid of nineteenth century women were involved in the work mostly inside the home, performed in other's home or an extension of traditional women's work which are done outside the home. Mostly women chose to work as cook, maid and as other household helpers by upper and middle class of the society. Nurses in the hospitals were even considered as the servants and their duty to fulfill the patient's basic need and to clean up (Jeri, 2010). There is not a problem with female achievement. Women have caught up with men in terms of education. In fact, in the United States and a number of other countries, women now actually surpass men in educational achievement. It is undeniable fact that a nation's edge over the other nations depends how it educates and utilize its feminist segement (WEF, 2015).The problem arises when young adults try to balance work and family, and women end up carrying nearly all of the caregiving responsibilities. Despite the fact that women have made enormous effors to make countable slopt in the lower ranks of the society, but the number of them has not secured top positions.

The change in workforce gender dynamics can be observed after World War II (1939-1945). This increase in number reported by U.S Department of Labor is $46 \%$ which is almost half of new jobs created by the today's economy for them (Elliot, 2000). The notion established that this huge representation might guarantee the equal treatment at work on all levels. Unfortunately, reality turns out to be different and females are still facing inequality issue not only in terms of compensation packages but also in exposing to better opportunities in their career. If women put many more hours into these household activities than men, this greatly disadvantages women in the workplace. It is unrealistic to expect gender equality if workplaces demand that women be available all the time.

There are number of researches that have been done by the scholars from the diversified fields of psychology, business and sociology on this issue and uncover various surprising elements behind this mindset. Prejudice against women in a workplace needs serious attention. Various researches give insight about the experiences of women at workplace. Many right ups confirmed this traditional perception that higher prospects are always depicted by a specific gender. Because being a female they are expected to perform some prime responsibilities like being a home maker or bearing children and this domestic phenomenon will affect their overall performance at workplace (Sandberg, 2013). A woman in such scenario tends to be overburdened since they have to work out of the box in order to prove her potential and meet the expectation which generally results into the psychological trauma. However, there have been considerable rise in the provision of subsidized childcare, which may also explicate the increase in female work force (Busso and Fonseca, 2015).It is expected by everyone to be treated on merit regardless of all the responsibilities and issues they are facing in their personal fronts. Moreover, men and women both expect that their performance should be judged regardless of their gender. As a society, we need to continue to encourage people to go beyond stereotypes and recognize the contributions that each individual, male or female, can make to the workplace and to relationships at home.

The main focus of this review article is to discuss and highlight the reasons that promote the inequality for 
women at workplace and not the history of women as the part of workforce particularly. Three phased strategy was used to write analytical review. First strategy was to search abstract of well-known researchers like Medline, Sociofile and PsychInfo. From their databases the combination of keywords from three domains were used that included; sex, gender, women, female, housewife, wife, mother, homemaker, or women in her pregnancy with work, employment, occupation or job with depression, health, well-being, illness, any disease, mortality, morbidity, endocrine or cardiovascular. The most relevant journals were taken into consideration for e.g. American Journal of Public Health, the Journals based on Social Behavior, Epidemiology, Social Psychology, Health, Medicine \& Social Science and other issues related to particularly women health.

In second phase references from books on employment and women's health or related topics were considered. We searched for the documents with at least one keyword from each domain in the title. The third and the last strategy used to retrieve the relevant data while contacting the active researchers in the similar areas to inquire about the work which is not yet published. Moreover, numerous institutions and organizations were contacted and information with reference to gender bigotry was retrieve. There were around 40 documents (articles, abstracts, dissertation \& thesis etc.) from which that to be included in the research analysis was then shortlisted.

The upcoming part is divided into six components; each part is itself a reason behind the inequality faced by women at work place with a brief review of research background that will help to strengthen its credibility. The following discussion will wrap up with considering the concept of women empowerment and other prevalent issues faced by women at workplace.

\section{Discrimination in assigning projects}

According to study conducted by Catalyst which is a non-profit organization, 1,660 graduates from business school were selected to examine assignments and projects that were assigned to high potential employees. The result shows that most of the critical projects or assignments that lead to promotions were given to men as compared to women. The statistics deduced by this study clearly confirms that while assigning challenging projects men are given priority as compared to women. The budget which was allotted for men's projects was twice as big and they were three times greater than women staffers. The budgets worth more than $\$ 10$ million were given to $30 \%$ of the male staff (high potential employees only) and only $22 \%$ of the female staff where the P\&L responsibility is only $46 \%$ is given to women versus $56 \%$ of the men. Furthermore, it was reported by three fourth of the male participants of this research that their assignments lead them to get a great deal of attention from the top management or C-suite, however on the other hand approximately quarter of female worker reported the same (Silva, Carter \& Anna Beninger, 2012).

\section{Reasons women OPT-OUT:}

"Opting Out? Why Women Really Quit Careers and Head Home" (University of California Press) is an American Sociological Association Award winning book which is written by Pamela Stone who is currently a Sociology Professor at Hunter College. Her study concluded that if high potential women are quitting their jobs, then they are not doing it on purpose but because they have to sacrifice their careers to look after their families and with work they can't maintain the balance. This study was conducted on 54 women, selected from four colleges and universities. These women were considered as high achievers and were recruited from the alumnae of the respective colleges and universities. These women had a career span of an average 11 years from which $60 \%$ women worked well after the birth of their second child. The results are very interesting when $90 \%$ women who opt out mentioned the reason was not their families but the unfavorable environment and problems they faced at workplace and also the frustrating nonflexible long hours. Out of these $90 \%$ women who sacrificed their jobs tried to get part-time jobs which they didn't find satisfactory. These females who were working part-time had been putting in long weeks where the actual meaning of part-time was 40 hours of work for 20 hours' worth of pay. That's why they chose a better option, in which they quit their jobs and stayed at home (Pamela Stone, 2013).

\section{Women vanish as corporate ladder goes up:}

The statistical study with 60 leading corporations by McKinsey (2012) revealed decreasing percentage of female workforce as we move on higher into the pyramid of the organization. It is about 325,000 women worked on entrylevel positions but only 150,000 made it to the middle management level that further reduce into 7,000 when they reach to the Vice President, Senior Vice President or CEO positions. In terms of percentage, females' representation is significantly less at higher ranks of organization. This study reveals this decrease in percentage as on average women in these selected corporations made up 53\% of entry-level employees, $40 \%$ of Managers, $35 \%$ of directors, $27 \%$ of vice presidents, $24 \%$ of senior vice presidents and only $19 \%$ of executives in the C-Suite (Barsh \& Yee, 2012).

\section{Compromises made on ethical values}

Laura Kray and Jessica Kennedy from Wharton and Haas School of Business respectively conducted a small study 
to identify the extent of their sacrifice and passion for success among men and women. The studies choose both gender to ascertain their reaction and opinion on different situations based on compromising on ethical values to achieve success at workplace. For example, asking them to respond on using some cheap and hazardous ingredient in their products for financial benefits. It was identified that female participants displayed the most outrage reaction as compared to men and found it difficult for them to make the business (Kennedy \& Laura 2013).

\section{Reluctance towards stereotypically masculine jobs}

Research was conducted to identify selection pattern which women follows when they are opting for a job. The results were surprising. According to the survey conducted by Mathhew Bidwell and Roxana Barbulescu women who were starting their MBA program in general management were found equally confident as the men in getting jobs after completion of their graduation. But it was not same for finance students.

This study reveals that females think that they were not suitable for finance related jobs, as they believe such jobs are stereotypical masculine jobs and can disturb their personal and professional life balance. They even believe that they will get less job offers as compared to men in such fields. However, research finds no evidence regarding this statement. (Barbulescy \& Matthew, 2012).

\section{Penalty for working Moms}

A female after giving birth to a child has to pay penalty for this status in terms of low pay or low promotional chances as they are getting perceived less committed and less competent among others. Empirical study was conducted with college students as they were asked to rate a pair of job applicants. Both applicants were equally qualified except the fact that one of the applicants was a parent. The results from this experiment were very astonishing as raters did not recommend mothers for the job. And those who recommended them advised to offer $\$ 11,000$ less as a starting salary as compared to a childless woman (Correll ,2013).

\section{Women Empowerment}

Fighting for their one's own rights and justice is not easy for any gender in our society. But particularly for women being a victor in the courtroom is quite expensive and daunting than a victim in the workplace because of the gender discrimination. However, unfortunately filing a lawsuit might be the only option for a women (in developed countries where gender discrimination is considered as an employment misconduct under law) to get the equal salary package or decision for advancement in job which are not usually based on one's effort, skill and responsibility but rather based on biased criteria.

Women who use career advancement techniques like asking for more responsibilities or by being proactive are usually disappointed, because these working women are provided with less advancement opportunities and less salary package as compared to males. Additionally, gender wage gap escalated due to discrimination.It has noted that women may be discriminated by employer on account of their subjective prejudice against women worker (Petreski and Mojsoska Blazevski, 2015) On top of everything, most frustrating situation faced by working women is when they realize that there is a huge difference between them and other males when it comes to position and salaries even though they used same advancement strategies. (Carter \& Silva, 2011).

It is however very essential for females to receive equal treatment by her employer. Skilled, passionate and organized working women are diminishing the stereotype which is there. It is also an obligation on a working women to support and help other women who join after them.

\section{Challenges and Constraints of Modern World}

This is an era of opportunities but one can see that majority of females are still struggling on a non significant positions with less authority. Moreover, the prospects of advancement and promotion also vary from their male counterparts though possess similar level of education.

However, this is also on record that many females compromise to accept lower positions in an organizations more willingly. This leads to less representation of them in top remarkable executive positions. This is commonly known as Glass Ceiling effect where top management discriminate the minorities or women while promoting them to executive level, not sure knowingly or unknowingly (Cotter, Hermsen, Ovadia \& Vanneman, 2001).

One of the most important reasons behind foregoing the promotional opportunities by women is the hindrance by their family. As stated, women are leaving their science, technology, engineering and mathematics careers in greater numbers than men because of care responsibilities (Mavriplis et al., 2010). It is one of the growing concerns in today's generation to achieve work-life balance. Almost in every society women is considered as a fundamental character in household for taking care of their family. It is an emerging issue for working females to manage their work life without disturbing their families and related household tasks. However, employer also need to plan, organize and maintain variety of work-based exercises, strategies and programs which not only benefit the organization itself but also help to make contribution in making society a better place to live and work in general. Research supported the fact that by initiating such conducive strategies for balance work-life turned out to be more 
cost-effective for promotion, recruitment, retention and overall productivity of an organization (Hill, Hawkins, Ferris \& Weitzman, 2001).

Modern world is categorized with technological advancement. Growing and extensive use of computers/internet and cell phones provided the opportunity to be connected to the workplace from anywhere at any time around the globe, whether be it at home or out for vacation or travelling in an aeroplane. Flexible working hours is another modern facility can be provided to the child bearing working women or women with kids who requires adult supervision. Moreover, providing child care facilities by the employers in the workplace are one way to support a balance between their employee's personal life and work.

Data collected during the research shows that there are many companies which offers family friendly policies as a perk like maternity benefits, health insurance, flexible work hours, working on Skype or telecommuting, parttime work options or job sharing are getting popularity (Keene, 2004). The research study also showed that women can excel in their careers if they simply avoid giving any hint to her employer regarding her commitment to her work, that it could be affected by her family responsibilities. (Baxter \& Wright, 2000).

It is suggested that there are few fundamental key points needed to be considered by women that will help them to minimize the conflict between a healthy family life and a successful professional career.

- Smart selection of Career

Job satisfaction can only be obtained when the person feel comfortable at work. Smart selection of career according to the aptitude will keep on multiplying the passion to work.

- Return to work - Beneficial for Everyone

Women should move on with an optimistic perspective while serving both family and the employer. The efforts and time invested by women in their career not only help them in elevating their professional career but also help them to improving their standard of living.

- $\quad$ Family as a Nucleus

A working woman has more responsibilities than working men. While keeping family as a central point, categorization of a career goals and setting financial targets make it easier for them to achieve them though very frustrating and tiring at the same time. Moreover, time management, goal/objective setting, dealing with continuous regret and frustration, searching available options, confidence building, balancing life and soul searching are all considered to be interconnected with each other (Hill, Hawkins, Ferris \& Weitzman, 2001). According to a survey top four complaints or challenges faced by women were identified.

First challenge which is usually faced by women in her working environment is that they feel discontented when their ideas and suggestions are dismissed and are not taken under consideration. Apart from this even in board meetings and in general discussions they are usually interrupted in the middle of their discussion and are not taken seriously. For instant, in a typical scenario if a woman gives her opinion regarding anything, it is usually ignored but if the same thing is restated by another man, his point of view is highly acknowledged.

Apart from this other challenge which was reported during the survey was that when it comes to any situation, women are always discriminated. For instance, if woman enter a meeting with a male associate, people generally assume male as the boss and female as an associate, but when they come to know about the reality then females at this point have to work extra hard to prove themselves that they are worthy enough for this position.

Third challenge is related to the struggle towards getting equity in employment which is a valid concept but in reality, it creates a wider gap between genders. The statements like, women get the job because she is a woman and men are losing job opportunities are the common lines women reported to hear on continuous basis.

Fourth and the foremost challenge which is faced by female workers is creating social contact with other colleagues. It is observed that informal gatherings are the actual source of relationship building but women tends to avoid them.one reason for avoiding these gatherings is that they hardly have any time remaining and other reason is that they have to maintain their female dignity as they are a member of conservative society. For example it is observed that whenever social events are organized, women workforce are usually excluded from these plans which provide them less chances for establishing their networking.

\section{Conclusion}

This article is actually a research roundup focusing on the gender inequality faced by women at workplace. Number of researches were studied while writing this article and each research revealed not only the reasons behind this inequality but also provides room for further studies which can find appropriate solution to minimize the discrimination at work places on gender basis. However, women is always considered to be a home maker in almost all the cultures from pre-industrial age to the technical age and involvement of women at workplaces is growing with time which cannot be ignored.

Studies also confirmed the fact that women at workplaces are more committed and organized then men, however her work-life balance has a great impact that pressurize her to opt out from job. Moreover, it is also revealed that better and challenging opportunities or projects are preferred to given to the men as compared to women, which creates great discouragement. When fewer opportunities are provided to the women they get less 
chance to gain the attention of $\mathrm{C}$-Suite and that leads to the decreasing number of women at higher ranks of the organization.

When it comes to ethical values, women find it unfair and more reluctant as compared to men to use unfair means to gain the profit or achieve the target. This reluctant attitude automatically reduce the likeability of women working in such fields that requires unusual flexibility.

Working women with a child faced more discrimination when compared to married men and women without child. Even the proven record of high potential women with children was unable to change this mindset of the raters.

To sum up all the researches discussed in earlier part of this article, it can be concluded that if women are provided ease at workplace and also support from their family, they can achieve as much as men can do. The only thing that need to be done is to provide them equal opportunities to prove themselves and unburden them from responsibilities other than work.

\section{References}

Jeri Freedman. (2010). Women in the Workplace: Wages, Respect, and Equal Rights. The Rosen Publishing Group. World Economic Forum (WEF). 2015. The global gender gap report 2015 (Geneva).

Sheryl Sandberg. (2013). Lean In: Women, Work, and the Will to Lead. Knopf Doubleday Publishing Group.

Busso, M.; Fonseca, D.R. 2015. Female labor force participation in Latin America: Patterns and

explanations, CEDLAS Working Paper 0187 (Buenos Aires, CEDLAS, Universidad Nacional de La Plata).

Petreski, M.; Mojsoska-Blazevski, N. 2015. The gender and motherhood wage gap in the Former

Yugoslav Republic of Macedonia. An econometric analysis (Geneva, ILO).

Christine Silva, Nancy M. Carter \& Anna Beninger. (2012). Good Intentions, Imperfect execution ? Women get fewer of the hot jobs needed to advance, Catalyst.

Pamela Stone. (2013). 'Opting Out': Challenging Stereotypes and creating real options for women in the profession. Harvard Business School.

Joanna Barsh \& Lareina Yee. (2012). Unlocking the full potential of women at work. Mckinsey \& Company.

Jessica A Kennedy \& Laura K.Kray. (2013). Who is willing to sacrifice ethical values for money and social status? Gender differences in reactions to ethical compromises. Social psychological \& Personality Science.

Roxana Barbulescy \& Matthew Bidwell. (2012). Do women choose different jobs from men?.Organization Science.

Shelley J. Correll. (2013). Minimizing the motherhood penalty: what workds and what doesn't and why. Harvard Business School.

Mavriplis, C.; Heller, R.; Beil, C.; Dam, K.; Yassinskaya, N.; Shaw, M.; Sorensen, C. 2010. "Mind the gap:Women in STEM career breaks", in Journal of Technology Management and Innovation, Vol. 5,No. 1, pp. 141-151.

Farrell, Warren (2005). Why men earn more: The startling truth behind the pay gap and what women can do about it. New York: AMACON.

Foschi, M. (2000). Double standards for competence: Theory and research. Annual Review of Sociology 26(1):2142.

Goldin, C., \& Rouse, C. (2000). Orchestrating impartiality: The impact of "blind auditions on female musicians. The American Economic Review, 90, 715-741.

Baxter, J., Wright, E., "The Glass Ceiling Hypothesis: A Reply to Critics", Gender and Society, Vol. 14 (6) 2000 , 814-821.

Bielby W. "Minimizing Workplace Gender and Racial Bias. Contemporary Sociology, Vol. 29 (1),2000 120-129.

Bielby W., Bielby D., "She Works Hard for the Money: Household Responsibilities and the Allocation of Work Effort", The American Journal of Sociology, Vol. 93( 5) 1988, 1031-1059.

Bielby W., Bielby D.," Family Ties: Balancing Commitments to Work and Family in Dual Earner Households" American Sociological Review, Vol. 54 ( 5 ) 1989, 776-789.

Blair-Loy, M., Wharton, A. , "Organizational Commitment and Constraints on Work-Family Policy Use: Corporate Flexibility Policies in a Global Firm", Sociological Perspectives, Vol. 47 (3), 2004, 243267. 